\title{
Surgical reduction of the renal mass in rats. Morphologic and functional analysis on the remnant kidney ${ }^{1}$
}

\author{
Redução cirúrgica da massa renal em ratos. Análise funcional e morfológica do rim \\ remanescente
}

\author{
Luiz Sérgio Santos², Eduardo Wei Kin Chin ${ }^{3}$, Sérgio Ossamu Ioshii ${ }^{4}$, Renato Tambara Filho ${ }^{5}$ \\ 1. Research performed at Surgical Technique and Experimental Surgery Laboratory, Catholic University of Paraná (PUC/PR) and Division \\ of Urology of Santa Casa de Curitiba-PR, Brazil \\ 2. Master, PhD in Surgery. Federal University of Parana (UFPR) - Urologist of the Division of Urology, Santa Casa de Curitiba-PR and \\ PUC/PR; Brazil \\ 3. MD, Resident at the Division of Urology, Santa Casa de Curitiba-PR, Brazil \\ 4. Associate Professor, Department of Pathology of PUC-PR and UFPR, Brazil \\ 5. Associate Professor, Division of Urology UFPR, Brazil
}

\begin{abstract}
ABSTRATC
Purpose: This study has analyzed the giochemical and morphological effects on the remmant kidney in rats which were submitted to progressive surgical ablation of renal mass. Methods: Sixty Wistar male rats, weighing between 210 and $380 \mathrm{~g}$, were used and they were distributed in 3 groups of 20 animals each. The rats from the groups called 1, 2 and 3 were submitted to the surgical removal of renal tissue equivalent to $1 / 2,2 / 3$ and $5 / 6$ of the whole renal mass, respectively. Then the groups were subdivided into 2 subgroups and they were operated again within 24 hours (subgroups 1B, 2B and 3B) and within 8 weeks (subgroups 1C, 2C and 3C) for the removal of the remnant kidney. 24-hour urine and blood were collected to analyze serum creatinine, clearance of creatinine and proteinuria in the first surgical intervention and at the time of the re-operation. The remnant kidney was submitted to a macroscopic evaluation for the degree of hypertrophy and to the analysis of histology. Results: There was a significant increase of the volume of the remnant kidney (164\%) and glomerular sclerosis was present in $40 \%$ of the animals submitted to the ablation of $5 / 6$ of renal mass. Functional alterations characterized by the increase of urinary excretion of proteins (50\% in group 3), rise in the serum creatinine (261\% subgroup 2B; 371\% subgroup 3B, 118\% subgroup 3C) and a significant reduction of the clearance of creatinine (control x subgroup $3 \mathrm{C}=2,88 \times 1,15 \mathrm{ml} / \mathrm{min}: \mathrm{p}<0,05$ were also observed. Conclusion: The compensatory renal hypertrophy, as well as the glomerular injury translated in the form of proteinuria and sclerosis, are closed related to the volume of the remnant kidney, thus they are more evident when a greater fraction of the renal tissue is excised.
\end{abstract}

Key words: Kidney. Nephrectomy. Surgery. Creatinine. Rats.

\section{RESUMO}

Objetivo: O estudo analisou os efeitos bioquímicos e morfológicos sobre o rim remanescente em ratos submetidos à ablação cirúrgica progressiva da massa renal. Métodos: Foram utilizados 60 ratos machos Wistar, pesando entre 210 e $380 \mathrm{~g}$, distribuídos em 3 grupos contendo 20 animais cada. Os ratos dos grupos denominados de 1,2 e 3 foram submetidos à remoção cirúrgica de tecido renal equivalente a 1/2, 2/3 e 5/6 da massa renal total, respectivamente. Os grupos foram então subdivididos em 2 subgrupos e reoperados em 24 horas (subgrupos 1B, 2B, 3B) e em 8 semanas (subgrupos 1C, 2C, 3C) para remoção do rim remanescente. Foram obtidas coletas de urina de 24 horas e sangue para análise da creatinina sérica, depuração da creatinina e proteinúria na primeira intervenção cirúrgica e por ocasião da reoperação. O rim remanescente foi submetido à avaliação macroscópica do grau de hipertrofia e à análise histológica. Resultados: Houve aumento significativo do volume do rim remanescente (164\%) e presença de esclerose glomerular em 40\% dos animais submetidos à ablação de 5/6 da massa renal. Alterações funcionais caracterizadas pelo aumento da excreção urinária de proteínas (50\% no grupo 3), elevação dos níveis séricos da creatinina (261\% subgrupo 2B; 371\% subgrupo 3B; 118\% subgrupo 3C) e redução significativa da depuração de creatinina (controle x subrupo 3C = 2,88 x 1,15ml/min :p<0,05) foram também observadas. Conclusão: A hipertrofia renal compensatória bem como a injúria glomerular traduzida sob a forma de proteinúria e esclerose estão intimamente relacionadas ao volume do rim remanescente, sendo, portanto, mais evidentes quando uma maior fração de tecido renal é extraída.

Descritores: Rim. Nefrectomia. Cirurgia. Creatinina. Ratos 


\section{Introduction}

The long term effects of unilateral nephrectomy have not been well defined yet. The removal of a kidney causes structural and functional alterations in the remnant kidney, in experimental and human models ${ }^{1,2}$. The primary answer is the hypertrophy of the contralateral kidney, called compensatory kidney hypertrophy $(\mathrm{CKH})$, which enables it to assume the functional role of the removed unit, becoming adequate to the metabolic demands of the organism. In practice, few collateral effects have been observed in the majority of patients and their survival does not seem to have been affected either ${ }^{3}$. However, recent clinical and experimental evidence suggest that these observations may not be truthful ${ }^{4}$.

Studies in rats have shown that after the partial removal of a kidney and the total removal of the other, there was a rise in the glomerular capillary pressure. This fact characterizes the state of adaptation, which associated to the consequent chronic hyperfiltration, causes increased proteinuria and progressive kidney failure. This is due to focal and segmented glomerular sclerosis observed in a significant number of animals ${ }^{5,6}$.

Many of the recent researches that aim to study the mechanisms of compensatory adaptation and eventual injuries which affect the remnant kidney are carried out in rats that were submitted to a progressive reduction of their renal mass, both the glomerular function and the characteristics of histology that may be altered after the ablation, are also analyzed, The evaluation of this data may determine the existence of predicting factors that may establish the prognostic of animals submitted to nephrectomy as for the possibility of evolving to the progression of renal disease and finally, renal failure.

This work aims at evaluating the functional and morphological alterations in the remnant kidney, which were observed when the total renal mass in rats was reduced in $1 / 2,2 / 3$ and $5 / 6$.

\section{Methods}

Sixty male Wistar rats were used (Rattus norvegicus albinos, Rodentia mammalian), their ages varied from 110 to 150 days and their weight varied from 210 to $380 \mathrm{~g}$. The rats were kept in the lab throughout the observation period under standard conditions - temperature between 20 and $24^{\circ} \mathrm{C}$, relative humidity between 50 and $60 \%$, controlled lighting (12-hour day/night cycle: $8 \mathrm{am} / 8 \mathrm{pm})$, were fed the standard feed for the species and were allowed water ad libitum. Within the 12 hours preceding the surgical procedure nothing was offered them except potable water. They were distributed, at random, in three groups for surgical ablation of $1 / 2,2 / 3$ and $5 / 6$ of the total renal mass according to what is described in table 1 . Then the animals were subdivided into 2 groups that were operated again within 24 hours (subgroup B) and within 8 weeks (subgroup C) to remove the remnant kidney. Throughout the study period, the provisions set by the "Colégio Brasileiro de Experimentação Animal” (COBEA) about the breeding and use of animals for teaching and research activities were followed. Anesthesia was induced by intramuscular injection of ketamine chlorhydrate $20 \mathrm{mg} / \mathrm{kg}$ and Xylazine $5 \mathrm{mg} / \mathrm{kg}$. Trichotomy and antisepsis of the ventral abdominal area were performed and the rats were placed in the horizontal dorsal decubitus position. A right-side nephrectomy through ventral incision was performed and a partial left-side nephrectomy through ventral incision was performed anda partial left-side nephrectomy as demonstrated below. After $24 \mathrm{~h}$ and 8 weeks the remnant kidney was removed by the same process.

\section{Groups distribution}

In order to dose proteinuria and the clearance of creatinine, urine was collected in the 24 hours preceding the surgical procedure. It was established as normal the proteinuria of 24 hours with values below or equal to $30 \mathrm{mg} /$ $24 \mathrm{~h}$ and as altered with values above $30 \mathrm{mg} / 24 \mathrm{~h}^{7}$. Blood samples were obtained for the dosing of serum creatinine in the immediate pre-operation period. For analysis intents, the glomerular filtration rate (GFR) was estimated by the clearance of endogenous creatinine ${ }^{8}$.

The analysis of the volume of the remnant kidney was calculated in cubic centimeters $\left(\mathrm{cm}^{3}\right)$ by using a manual sliding caliper graded in millimeters. The measurements were obtained immediately after the ablation of the renal tissue and at the time of euthanasia, when the whole kidney was removed. After the removal of the renal tissue, it was put in a solution of formalin at $10 \%$ for 24 hours. The sampled material was submitted to a conventional histology preparation and colored with hematoxylin-eosin (H\&E). The analysis of the parameters for histology and morphology (average glomerular diameter and the presence, or not, of glomerular sclerosis) was carried out by means of optical microscopy (Table 1).

Glomerular sclerosis with segmental injury was defined as areas of the glomerular tuft showing collapse of the capillary glomerulars frequently accompanied by hyaline deposition and/or adherence of the tuft to the Bowman capsule. The focal injury was established when only some glomeruli were altered by sclerosis ${ }^{9}$.

The samples being studied were compared to the histology characteristics of the tissues obtained in the first surgery, after the re-operation within 24 hours and after 8 weeks. The alterations in histology that were observed were analyzed and related to the amount of renal tissue that was excised. In order to prove the objectives raised in the study, the following tests were used: the parameter test " $\mathrm{t}$ de Student" (Software "Primer Biostatistics"), and the nonparameter ones "Mann-Whitney”, "Qui-Quadrado with Yates correction” and "Exact by Fisher” (by software "EpiInfo"). It was adopted $5 \%$ as the level of minimal significance. 
TABLE 1 - Groups distribution

\begin{tabular}{l|l|c|c|c|c}
\hline GROUPS & \multicolumn{1}{|c|}{ Operatory technique } & $\begin{array}{c}\text { Control } \\
\text { Preoperative }\end{array}$ & $\begin{array}{c}\text { Subgroup B } \\
\text { 24 hours }\end{array}$ & $\begin{array}{c}\text { Subgroup C } \\
\mathbf{8} \text { weeks }\end{array}$ & TOTAL \\
\hline Group 1 & Right Nephrectomy (1/2 total renal mass) & $\mathrm{n}=20(1 \mathrm{~A})$ & $\mathrm{n}=10(1 \mathrm{~B})$ & $\mathrm{n}=10(1 \mathrm{C})$ & $\mathrm{n}=20$ \\
\hline Group 2 & $\begin{array}{l}\text { Right Nephrectomy + ressection of left renal } \\
\text { inferior pole (2/3 total renal mass) }\end{array}$ & $\mathrm{n}=20(2 \mathrm{~A})$ & $\mathrm{n}=10(2 \mathrm{~B})$ & $\mathrm{n}=10(2 \mathrm{C})$ & $\mathrm{n}=20$ \\
\hline Group 3 & $\begin{array}{l}\text { Right Nephrectomy + ressection of left renal } \\
\text { inferior and superior pole (5/6 total renal mass) }\end{array}$ & $\mathrm{n}=20(3 \mathrm{~A})$ & $\mathrm{n}=10(3 \mathrm{~B})$ & $\mathrm{n}=10(3 \mathrm{C})$ & $\mathrm{n}=20$ \\
\hline TOTAL & & & & & $\mathbf{n}=\mathbf{6 0}$ \\
\hline
\end{tabular}

Note: The control group (preoperative) generated the subgroups of 24 hours and 8 weeks.

\section{Results}

The results referring to the biochemical data of serum creatinine, clearance of creatinine and proteinuria, observed in control group and at the moment of re-operation, are shown in Table 2. The proteinuria data were analyzed according to the absolute number of animals in each group and the corresponding percentage value.

Results of creatinine $(\mathrm{mg} / \mathrm{dl})$, creatinine clearance ( $\mathrm{ml} / \mathrm{min})$ and proteinuria $(\mathrm{mg} / \mathrm{dl})$

The variation of the values relating to the clearance of creatinine found in groups 1, 2 and 3 are shown in Figure 1, as well as the percentage of residual renal function (Table 2).

Table 3 and Figure 2 summarize the data relating to the remnant renal volume in the control and at the moment of re-operation in the various groups, as well as the analysis of the percentage of gain in renal mass observed in 24 hours (subgroups 1B, 2B and $3 \mathrm{~B}$ ) and in 8 weeks (subgroups $1 \mathrm{C}$, 2C and 3C).

The data observed in the histology test of the renal tissue excised in groups 1, 2 and 3 are shown in Table 4 . The presence of glomerular sclerosis is expressed in number of cases and their percentage.

TABLE 2 - Results of creatinine (mg/dl), creatinine clearance (ml/min) and proteinuria (mg/dl)

\begin{tabular}{|c|c|c|c|}
\hline RESULTS & $\begin{array}{c}A \\
(n=20)\end{array}$ & $\begin{array}{c}\text { B } \\
(n=10)\end{array}$ & $\begin{array}{c}C \\
(n=10)\end{array}$ \\
\hline \multicolumn{4}{|c|}{ Serum creatinine } \\
\hline Group 1 & $0,35 \pm 0,23$ & $0,49 \pm 0,33$ & $0,32 \pm 0,12$ \\
\hline Group 2 & $0,26 \pm 0,07$ & $0,94 * \pm 0,36$ & $0,63 \pm 0,53$ \\
\hline Group 3 & $0,32 \pm 0,11$ & $1,52 * \pm 0,96$ & $0,70 * \pm 0,15$ \\
\hline \multicolumn{4}{|c|}{ Creatinine clearence } \\
\hline Group 1 & $2,92 \pm 2,07$ & $1,13^{*} \pm 0,51$ & $2,72 \pm 0,96$ \\
\hline Group 2 & $2,72 \pm 1,24$ & $0,65^{*} \pm 0,29$ & $1,90 \pm 1,00$ \\
\hline Group 3 & $2,88 \pm 1,75$ & $0,66 * \pm 0,87$ & $1,15 \pm 0,77$ \\
\hline \multicolumn{4}{|l|}{ Proteinuria } \\
\hline Group 1 & $0210,0 \%$ & $0,6 * 60,0 \%$ & $03 \quad 30,0 \%$ \\
\hline Group 2 & $0315,0 \%$ & $0,9 * 90,0 \%$ & $04 \quad 40,0 \%$ \\
\hline Group 3 & $04 \quad 20,0 \%$ & $0,6^{*} \quad 60,0 \%$ & $05 \quad 50,0 \%$ \\
\hline
\end{tabular}

* Serum Creatinine: $2 B>2 A, p<0,0001$; $3 B>3 A, p=0,002$; $3 C>3 A, p<0,0001$ e $3 B>3 C, p=0,031$

Creatinine clearence: $1 \mathrm{~B}<1 \mathrm{~A}, \mathrm{p}=0,002 ; 1 \mathrm{~B}<1 \mathrm{C}, \mathrm{p}=0,001 ; 2 \mathrm{~B}<2 \mathrm{~A}, \mathrm{p}<0,0001 ; 2 \mathrm{~B}<2 \mathrm{C}, \mathrm{p}=0,006$; $3 \mathrm{~B}<3 \mathrm{~A}, \mathrm{p}<0,0001 ; 3 \mathrm{C}<3 \mathrm{~A}, \mathrm{p}<0,0001 \mathrm{e}$ $3 \mathrm{~B}<3 \mathrm{C}, \mathrm{p}=0,017$.

Proteinuria: $1 \mathrm{~B}>1 \mathrm{~A}, \mathrm{p}=0,0072 ; 2 \mathrm{~B}>2 \mathrm{~A}, \mathrm{p}=0,0001 ; 3 \mathrm{~B}>3 \mathrm{~A}, \mathrm{p}=0,0387$

TABLE 3 - Remnant kidney's volume in the groups $\left(\mathrm{cm}^{3}\right)$

\begin{tabular}{ccccccc}
\hline GROUPS & $\mathbf{A}$ & $\mathbf{B}$ & $\mathbf{C}$ & & \multicolumn{2}{c}{ \% MASS INCREASING } \\
& $\mathbf{( n = 2 0 )}$ & $\mathbf{( n = 1 0 )}$ & $\mathbf{( n = 1 0 )}$ & $\mathbf{A}: \mathbf{B}$ & $\mathbf{A}: \mathbf{C}$ & $\mathbf{B}: \mathbf{C}$ \\
\hline 1 & 1,25 & 1,43 & 2,42 & 14,4 & 93,6 & 69,2 \\
2 & 0,83 & 1,11 & 1,56 & 33,7 & 88,0 & 40,5 \\
3 & 0,53 & 0,83 & 1,93 & 56,6 & 164,2 & 132,5 \\
\hline
\end{tabular}


TABLE 4 - Histological results

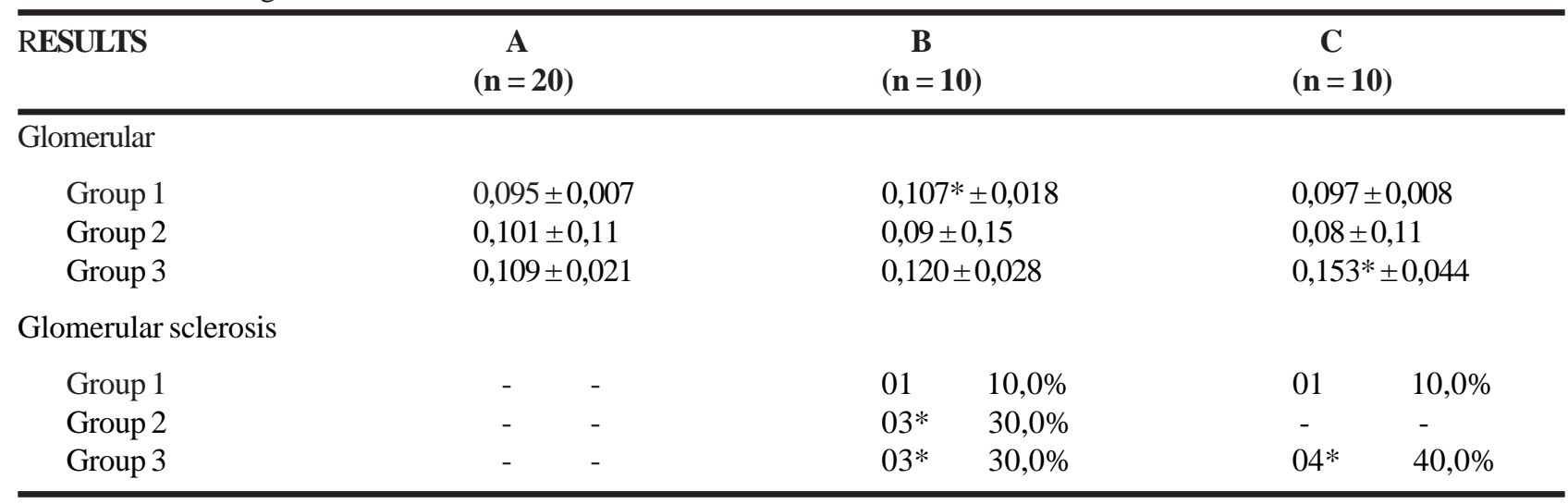

(*) Glomerular diameter: $1 \mathrm{~B}>1 \mathrm{~A} ; \mathrm{p}<0,0001 ; 3 \mathrm{C}>3 \mathrm{~A}, \mathrm{p}<0,0001$;

Glomerular sclerosis: $2 \mathrm{~B}>2 \mathrm{~A}, \mathrm{p}=0,0296 ; 3 \mathrm{~B}>3 \mathrm{~A}, \mathrm{p}=0,0296$ e $3 \mathrm{C}>3 \mathrm{~A}, \mathrm{p}=0,0077$

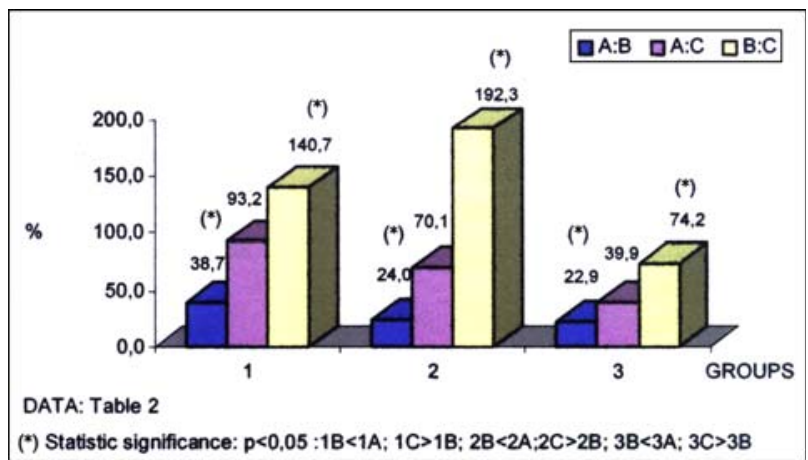

FIGURE 1 - Percentual of residual renal function

\section{Discussion}

In this experimental model, there was a rise in the serum levels of creatinine in all the groups, with significant variation in the animals in which the ablation was more than $50 \%$ of the total renal mass, according to what was shown in the animals of subgroups $2 \mathrm{~B}$ and $3 \mathrm{~B}$, whose rise was $261 \%(p<0,0001)$ and $371 \%(p<0,002)$, respectively. This rise was more intense in the first 24 hours, there was a significant functional recuperation within 8 weeks, probably due to a compensatory renal hypertrophy that was developed. The functional recuperation of the remnant kidney, evaluated by means of the serum creatinine, was inversely proportional to the percentage of the renal tissue excised, giving support to other similar studies ${ }^{10,11}$.

The recuperation of the GFR analyzed together with the hypertrophy of the remnant kidney was better observed within 8 weeks in the 3 distinct groups. In groups 1 and 2, in spite of the emphasized reduction in the levels of clearance of creatinine evident in the first 24 hours after the renal ablation, there was satisfactory recuperation in the total renal function, as it became closer, in these groups, to the initial pre-nephrectomy values. After the removal of 5/6 of the renal mass (group 3), the clearance of creatinine reduced to $23 \%$ of the total in 24 hours, stabilizing, after 8 weeks, in $40 \%$ of the values obtained by both kidneys previously. These data are in accordance to the report of a similar study that observed a strong reduction of GFR to $17 \%$, checked

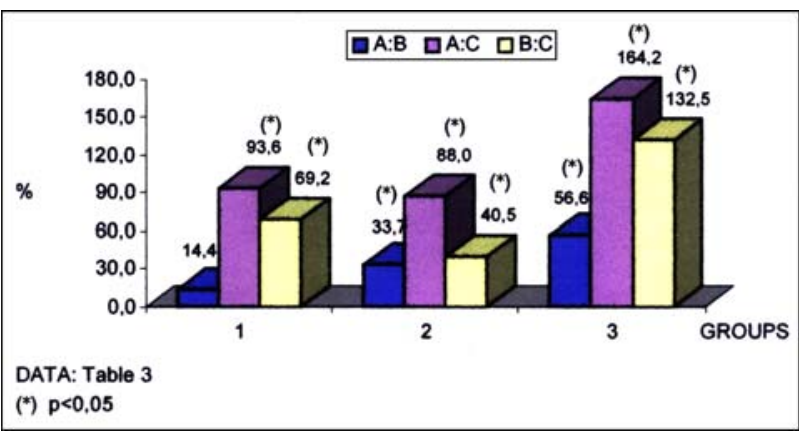

FIGURE 2 - Percentual of renal mass increasing

in the 24 hours after the renal ablation, followed by progressive recuperation by means of the increase of the remnant renal mass ${ }^{12}$.

Eight weeks after the nephrectomy there was satisfactory functional recuperation of the remnant kidney in all the groups of animals relating to the control group and also, a significant increase of the renal function when compared to the groups within 24 hours, mainly in the animals of group $2(0,65 \times 1,90 \mathrm{ml} / \mathrm{min}, \mathrm{p}=0,006)$. However, it is possible that values closer to normality are found within a period of grater observation ${ }^{13-15}$.

In general, when the number of nephrons is reduced, the rise in the levels of proteinuria is followed by glomerular hyperthrophy and hyperfiltration. In uninephrectomized rats the proteinuria represents a early marker of the increase of the glomerular permeability making it possible to identify a subclinical renal disease ${ }^{16}$.

In this series, there was the occurrence of massive proteinuria in the groups re-operated within 24 hours (1B, $2 \mathrm{~B}$ and $3 \mathrm{~B}$ ) due to renal manipulation and consequent hematuria; this made it difficult to have a correct laboratory analysis, and that was the reason it was not considered and only the analysis of the proteinuria obtained in 8 weeks was used. Significant alterations were not evident in the levels of proteinuria in 8 weeks, when compared to the control group in all the subgroups studied. However, in subgroup 3C, where the largest reduction of renal tissue was carried out, it was observed an alteration in the levels 
of proteinuria, above $30 \mathrm{mg} / 24$ hours, in approximately $50 \%$ of the animals, there was no statistic significance, though (table2). Although significant alterations were not found in the groups being studied, it is possible that the proteinuria secondary to the removal of renal mass may be better interpreted in a bigger sample and in longer observation time and thus effectively represent a marker of the residual renal function, as it has been suggested by other authors ${ }^{17-}$ ${ }^{18}$. Data relating to proteinuria may also predict, in the future, the degree of susceptibility for the development of terminal renal failure in the animals submitted to an extensive ablation of renal tissue. The volume of the remnant kidney increased in all the groups of rats in relation to the initial volume. There was no statistic different only in relation to the subgroup $1 \mathrm{~B}$ when the renal volume was compared between the moment of operation and 24 hours later. However, an emphasized increase of renal dimensions (93.6\%) was observed when they were analyzed within 8 weeks. These values were proportionally comparable to the ones found by other studies that observed an increase from $66 \%$ to $114 \%$ in the renal volume after unilateral nephrectomy within the period of time going from 4 to 8 weeks ${ }^{3,19,20}$.

The increase of the glomerular diameter resulting from the removal or destruction of functioning glomeruli corresponds to one of the main hemodynamics alterations that are responsible for the mechanisms of renal compensation as an answer to kidney aggression ${ }^{8}$.

When analyzing the variation of the glomerular diameter in the control and at the moment of the re-operation, a significant alteration was observed, mainly in group 3 . The increase of the glomerular diameter happened in the first 24 hours, giving indication that the effects of renal hyperflux and compensatory alterations start immediately after the renal ablation. Within 8 weeks, in the same group, an average increase of $40 \%$ was observed in the glomerular diameter, in relation to the control group (table 4). The presence of glomerular lesions with statistical relevance was observed mainly in the group with bigger reduction of renal mass (subgroup 3B, 30\%). This fact reveals the possible presence of glomerular lesion within the first hours of injury or, eventually, it may mean the external deposition of proteic matter in the mesangial matrix, which is colored by PAS and makes it difficult to interpret glomerular sclerosis correctly in its initial phase. Within 8 weeks (subgroup 3C), when the adapting changes secondary to the renal ablation were well established, glomerular sclerosis was observed in $40 \%$ of the rats in this subgroup. A result similar to the one found by other authors, which proves that extensive ablation of the renal mass may lead to glomerular sclerosis and finally to renal failure, even through the initial aggression to the kidney has already ended ${ }^{7,9}$.

These observations show that the extension of compensatory renal growth is intimately related to the percentage of renal tissue that is surgically removed. The structural alterations, through which the remnant kidney passes, have as main aim retaking the previous functional balance by means of complex and multi-factor mechanisms of compensatory adaptation.

\section{Conclusion}

This study shows that compensatory renal hypertrophy as well as glomerular injury translated in the form of proteinuria and sclerosis are closely related to the volume of the remnant kidney and to the period of observation, thus they are more evident when a greater fraction of renal tissue is excised.

\section{References}

1. Anderson S, Meyer TW, Brenner BM. The role of hemodynamic factors in the initiation and progression of renal disease. J Urol. 1985;133:363-8.

2. Zerin JM, Haliloglu M, Cohen MD. Grow of solitary kidney after nephrectomy in children with unilateral Wilms’ tumor. Pediatr Radiol. 1996;26:547-52.

3. Argueso LR, Ritchey ML, Boyle Jr ET, Milliner DS, Bergstralh EJ, Kramer SA. Prognosis of children with solitary kidney after unilateral nephrectomy. J Urol. 1992;148:747-51.

4. Rugiu C, Oldrizzi L, Maschio G. Renal reserve in patients with solitary kidneys. Semin Nephrol. 1995;15:468-74.

5. Anderson S, Meyer TW, Rennke HG, Brenner BM. Control of glomerular hypertension limits glomerular injury in rats with reduced renal mass. J Clin Invest. 1985;76:612-9.

6. Pelayo JC, Westcott JY. Impaired autoregulation of glomerular capillary hydrostatic pressure in the rat remnant nephron. J Clin Invest. 1991;88:101-5.

7. Floege J, Burns MW, Alpers CE, Yoshimura A, Gordon K, Seifert RA, Bowen-Pope DF, Couser WG, Johnson RJ. Glomerular cell proliferation and PDGF expression precede glomerulosclerosis in the remnant kidney model. Kidney Int. 1992;41:297-309.

8. Maluf NSR, Ford RV, Spurr CS. Physiology of human solitary kidney. J Urol. 1957;78:117-31.

9. Lafayette RA, Mayer G. Park SK, Meyer TW. Angiotensin II receptor blockade limits glomerular injury in rats with reduced renal mass. J Clin Invest. 1992;90:766-71.

10. Bidani AK, Schwartz MM, Lewis EJ. Renal autoregulation and vulnerability to hypertensive injury in remnant kidney. Am J Physiol. 1987;252:1003-10.

11. Orisio S, Beningni A, Bruzzi I, Corna D, Perion N, Zoja C, Benatti L, Remuzzi G. Renal endothelin gene expression is increased in remnant kidney and correlates with disease progression. Kidney Int. 1993;43:354-8.

12. Miller SB, Hansen VA, Hammerman MR. Effects of growth hormone and IGF-I on renal function in rats with normal and reduced renal mass. Am J Physiol. 1990;259:747-51.

13. Schwartz MM, Evans J, Bidani AK. The mesangium in the long-term remnant kidney model. J Lab Clin Med. 1994;124:644-51.

14. Lax DS, Benstein JA, Tolbert E, Dworkin LD. Effects of salt restriction on renal growth and glomerular injury in rats with remnant kidneys. Kidney Int. 1992;41:1527-34. 
15. Silber S, Malvin RL. Compensatory and obligatory renal growth in rats. Am J Physiol. 1974;226:114-7.

16. Kenner CH, Evan AP, Blomgren P, Aronoff GR, Luft FC. Effect of protein intake on renal function and structure in partially nephrecotmized rats. Kidney Int. 1985;27:739-50.

17. Kasiske BL, Ma JZ, Louis TA, Swan SK. Long-term effects of reduced renal mass in humans. Kidney Int. 1995;48:814-9.
18. Yoshioka T, Shiraga H, Yoshida Y, Fogo A, Glick AD, Deen WM, Hoyer JR, Ichikawa I. "Intact Nephrons” as the primary origin of proteinuria in chronic renal disease. J Clin Invest. 1988;82:1614-23.

19. Hayslett JP. Effect of age on compensatory renal growth. Kidney Int. 1983;23:599-602.

20. Mulroney SE, Woda C, Johnson M, Pesce C. Gender differences in renal growth and function uninephrectomy in adult rats. Kidney Int. 1999;56:944-53.

\section{Correspondence:}

Luiz Sergio Santos

Rua Visconde de Nacar, 865/507

80410-201 Curitiba-PR Brazil

Phone: (55 41)3233-6412

luizsergio@mps.com.br
Conflict of interest: none Financial source: none

Received: January 08, 2006 Review: February 14, 2006

Accepted: March 16, 2006

\section{How to cite this article:}

Santos LS, Chin EWK, Ioshii SO, Tambar Filho R. Surgical reduction of the renal mass in rats. Morphologic and functional analysis on the remnant kidney. Acta Cir Bras. [serial on the Internet] 2006 July-Aug;21(4). Available from URL: http://www.scielo.br/acb 